\title{
Politik Hukum Ketentuan Pidana Atas Undang-Undang Nomor 22 Tahun 2001 Tentang Minyak Dan Gas Bumi (Studi Dampak Pencemaran Lingkungan Akibat Bencana Lumpur Lapindo)
}

\author{
Siti Sarah Astuti \\ Magister Hukum Fakultas Hukum Universitas Islam Indonesia Yogyakarta Indonesia \\ Jln. Cik Di Tiro No. 1 Yogyakarta Indonesia \\ sarah14504@yahoo.com
}

\begin{abstract}
This study aims to determine the environmental pollution caused by the Lapindo mud disaster and legal politics in terms of the criminal provisions in Law No. 22 of 2001 concerning Oil and Gas. The problems formulated in this research are first, what is the legal politics of the criminal provisions of Law Number 22 of 2001 on Oil and Gas? Second, what is the impact of the Lapindo mudflow on the environment and public health? The type of research is normative with a statutory approach and is analyzed using qualitative methods. The results of this study are first, the legal politics regarding the Lapindo mud disaster, namely the absence of an article that regulates violations regarding procedural errors committed by companies in the Criminal Provisions of Law Number 22 of 2001 on Oil and Gas. Second, local residents suffered losses, both material and immaterial, because Lapindo mud contains chemical substances, namely metals and phenols that endanger public health and pollute the environment such as water, soil, and air.
\end{abstract}

Key Words: Environtment; lapindo mud; legal policy; public health

\begin{abstract}
Abstrak
Penelitian ini bertujuan untuk mengetahui pencemaran lingkungan yang disebabkan oleh bencana lumpur lapindo dan politik hukum yang ditinjau dari ketentuan pidana di Undang-Undang Nomor 22 Tahun 2001 tentang Minyak dan Gas Bumi. Masalah yang dirumuskan dalam penelitian ini adalah pertama, bagaimana politik hukum ketentuan pidana atas Undang-Undang Nomor 22 Tahun 2001 tentang Minyak dan Gas Bumi? Kedua apa dampak semburan lumpur lapindo terhadap lingkungan dan kesehatan masyarakat? Jenis penelitian ini bersifat normatif dengan pendekatan perundangundangan dan dianalisa menggunakan metode kualitatif. Hasil penelitian ini menyimpulkan, pertama, politik hukum mengenai bencana lumpur lapindo yaitu tidak adanya pasal yang mengatur tentang pelanggaran mengenai kesalahan prosedural yang dilakukan oleh perusahaan di Ketentuan Pidana Undang-Undang Nomor 22 Tahun 2001 tentang Minyak dan Gas Bumi. Kedua, warga sekitar mengalami kerugian, baik materil dan immateril, karena lumpur lapindo mengandung zat kimia yaitu logam dan fenol yang membahayakan kesehatan masyarakat dan mencemari lingkungan seperti air, tanah, dan udara.
\end{abstract}

Kata-kata Kunci : Lumpur lapindo; politik hukum; lingkungan; kesehatan masyarakat 


\section{Pendahuluan}

Undang-Undang Dasar 1945 telah menyebutkan bahwa salah satu Hak Asasi Manusia yang harus terpenuhi adalah mengenai tempat tinggal dan lingkungan hidup yang baik, sebagaimana dimaksud dalam Pasal $28 \mathrm{H}$ ayat (1) yang berbunyi: "Setiap orang berhak hidup sejahtera lahir dan batin, bertempat tinggal, dan mendapatkan lingkungan hidup yang baik dan sehat serta berhak memperoleh pelayanan kesehatan." Tindak lanjut dari pasal tersebut dituangkan ke dalam UndangUndang Nomor 32 Tahun 2009 tentang Perlindungan dan Pengelolaan Lingkungan Hidup. Namun, dengan adanya peraturan tersebut belum semua masyarakat individu maupun badan hukum menjalani aturan-aturan tersebut dengan patuh dan tingkat kesadaran lingkungan hidup rendah, sehingga berdampak negatif kepada masyarakat kecil yang notabene tidak mempunyai kuasa dan kedudukan agar bisa melawan penguasa yang menimbulkan kerugian tersebut.

Masalah lainnya adalah kemungkinan adanya ketentuan tertentu yang belum diatur dalam undang - undang yang sudah dikeluarkan oleh pemerintah, sehingga dalam praktiknya menimbulkan kerugian bagi masyarakat ditambah lagi sistem hukum di Indonesia yang masih lemah sehingga sering terjadinya negosiasi antara para penguasa dan sering terjadinya eigenrichting.

Kesadaran lingkungan hidup pada intinya adalah kesadaran tentang adanya masalah lingkungan hidup yang dihadapi dengan berbagai implikasinya, serta bagaimana menanggulangi masalah tersebut. Seharusnya kesadaran ini dapat mendorong manusia mempelajari seluk-beluk lingkungan hidup serta bagaimana memanfaatkan sumber daya alam pada lingkungan hidup ini secara berkelanjutan sehingga melahirkan upaya Pengelolaan Lingkungan Hidup (PLH) yang kemudian disebut Perlindungan dan Pengelolaan Lingkungan Hidup (PPLH). Guna menunjang PLH/PPLH ini dikembangkanlah hukum lingkungan sebagai sarana penunjangnya. Hukum lingkungan adalah salah satu sarana penunjang PPLH yang diharapkan dapat menyerasikan pemanfaatan dan pemeliharaan sumber daya alam dan lingkungan hidup guna menjamin pemanfaatannya secara berkelanjutan. ${ }^{1}$

Dalam UUPPLH ditegaskan bahwa salah satu tujuan perlindungan dan pengelolaan lingkungan hidup adalah menjamin pemenuhan dan perlindungan hak atas lingkungan hidup yang baik dan sehat sebagai bagian dari Hak Asasi Manusia. Konsepsi ini mengakomodir dua hak sekaligus, yaitu hak lingkungan atas kualitas lingkungan hidup yang baik dan hak manusia untuk menikmati lingkungan hidup tersebut sehingga kehidupan dapat berjalan dengan harmonis.

${ }^{1}$ Yunus Wahid, Pengantar Hukum Lingkungan, Prenadamedia Group, Jakarta, 2018, hlm. 52. 
Oleh karena itu, perlu dipahami bahwa manusia dan lingkungan hidup merupakan dua unsur yang mempunyai kedudukan yang sama dalam hukum lingkungan sebagai subjek hukum yang menentukan bekerjanya sistem kehidupan. Kepentingan manusia tidaklah berdiri sendiri, melainkan juga merupakan kepentingan lingkungan hidup dan keduanya merupakan satu kesatuan yang membentuk sistem kehidupan tersebut. ${ }^{2}$

Definisi dari Hukum Lingkungan sendiri adalah salah satu cabang dalam disiplin ilmu hukum yang berkaitan dengan pengaturan hukum terhadap perilaku atau kegiatan-kegiatan subjek hukum dalam pemanfaatan dan perlindungan sumber daya alam dan lingkungan hidup serta perlindungan manusia dari dampak negatif yang timbul akibat pemanfaatan sumber daya alam. Dengan demikian, hukum lingkungan tidak senantiasa berkaitan dengan pengaturan perlindungan lingkungan hidup dalam arti pelestarian lingkungan, tetapi juga berkaitan dengan pengaturan pemanfaatan atau penggunaan sumber daya alam seperti air, tanah, laut, hutan, dan bahan tambang. ${ }^{3}$

Pembangunan konkretnya kegiatan yang dilakukan oleh manusia dalam menjalani dan memperbaiki hidup dan kehidupannya senantiasa memanfaatkan unsur-unsur sumber daya alam dan lingkungan hidup dan berlangsung pada lingkungan hidup tertentu. Kegiatan ini adalah tuntutan hidup yang sangat manusiawi, bahkan merupakan suatu kemutlakan bila manusia ingin tetap eksis dalam kehidupan berbudaya ini secara wajar yang tidak boleh dipertentangkan dengan tuntutan ekologi agar tetap stabil dan dinamis.

Persaingan bebas industri minyak bumi dan mineral secara legal dimulai sejak diundangkannya Undang-Undang Nomor 22 Tahun 2001 tentang Minyak dan Gas Bumi yang mengijinkan pihak swasta untuk boleh melakukan kegiatan tersebut, baik di sektor hulu maupun hilir. Aturan dalam UU ini membuka peluang bagi sektor swasta domestik dan internasional untuk beroperasi di Indonesia tanpa intervensi dari pemerintah. Namun jauh sebelum diundangkannya UU tersebut, bukan berarti tidak ada pihak swasta domestik ataupun asing yang masuk dalam pengusahaan minyak dan gas bumi. ${ }^{4}$

Dalam praktiknya, kegiatan badan hukum dalam menjalankan pembangunan sering terjadi ketidakseimbangan antara dampak lingkungan dengan kegiatan badan hukum tersebut. Misalnya kasus Lumpur Lapindo yang menyemburkan lumpur panas di lokasi pengeboran Lapindo Brantas Inc., di

2 Masrudi Muchtar, Noraida, dan Abdul Khair, Hukum Kesehatan Lingkungan (Kajian Teoritis dan Perkembangan Pemikiran), Pustaka Baru Press, Yogyakarta, 2016, hlm. 39.

3 Takdir Rahmadi, Hukum Lingkungan di Indonesia, PT Rajagrafindo Persada, Depok, 2015, hlm. 21.

4 Anis Farida, "Jalan Panjang Penyelesaian Konflik Kasus Lumpur Lapindo", Jurnal Ilmu Sosial dan Ilmu Politik, No. 2, Vol. 17, 2013, hlm. 9. 
Kecamatan Porong, Kabupaten Sidoarjo, Jawa Timur. Semburan lumpur panas ini menyebabkan tergenangnya kawasan permukiman dan pertanian di tiga kecamatan sekitarnya. ${ }^{5}$

Lapindo Brantas Inc., pertama kali didirikan pada 1996 setelah proses kepemilikan sahamnya diambil alih dari perusahaan yang berbasis di Amerika, Huffington Corporation. Saat itu pihak Lapindo Brantas sudah menandatangani kontrak kerjasama dengan Pertamina selaku pihak yang mengelola industri tambang. Lapindo Brantas Inc. merupakan perusahaan eksplorasi gas dan minyak yang merupakan joint venture antara PT Energi Mega Persada Tbk., PT Medco Energi Tbk., dan Santos Australia. Keluarga Bakrie melalui investasinya memegang kendali atas PT Energi Mega Persada Tbk. Itulah sejarah terlibatnya Lapindo Brantas dalam usaha pengelolaan minyak dan gas bumi di Blok Brantas Jawa Timur, termasuk Sidoarjo. ${ }^{6}$

Akibat kelalaian PT Lapindo menyebabkan lumpur panas dari perut bumi meluap keluar. Semburan lumpur lapindo juga berdampak pada pencemaran air, tanah, dan udara. Kondisi lingkungan yang tercemar dapat mempengaruhi kesehatan warga sekitar. Bencana lumpur lapindo jelas telah merugikan masyarakat akibat kesalahan teknis pengeboran yang dilakukan oleh PT Lapindo Brantas. Warga penyintas Lumpur Lapindo mengungkapkan saat masih tinggal di sekitar tanggul lumpur, dirinya bersama keluarga sering menghirup bau menyengat dan kurang sedap yang terbawa oleh angin. Bahkan saat sudah pindah agak jauh dari pusat semburan, bau tidak sedap masih sesekali tercium saat angin berhembus kencang. Kondisi lingkungan yang tercemar dapat mempengaruhi kesehatan warga.

Berdasarkan pemeriksaan kesehatan yang telah dilakukan sebelumnya terhadap 20 orang penyintas secara acak, ditemukan 10 orang atau 50 persen mengalami kelainan pada pemeriksaan darah dan urin. Sedangkan 4 orang penyintas atau 20 persen mengalami kelainan pada pemeriksaan toraks. Temuan ini menguatkan penulisan sebelumnya oleh Balai Besar Teknik Kesehatan Lingkungan dan Pengendalian Penyakit Menular (BTKL PPM) pada 2010, yaitu 81 persen sampel warga di Desa Besuki, Glagaharum, Gempolsari, Kali Tengah, mengalami gangguan restriksi paru-paru. ${ }^{7}$

5 Satrio, Bungkus Pratikno, dan Paston Sidauruk, "Studi Asal-Usul Air Lumpur Lapindo Periode 20072012 Menggunakan Isotop Alam”, Jurnal Ilmiah Isotop dan Radiasi, No. 2, Vol. 8, Tahun 2012, hlm. 2.

${ }^{6}$ Anis Farida, "Jalan..., Op. Cit., hlm. 9.

7https://www.voaindonesia.com/a/kasus-lapindo-12-tahun-semburan-lumpur-ancam-kesehatanwarga/4415812.html, "Kasus Lapindo: 12 Tahun Semburan Lumpur Ancam Kesehatan Warga", diakses 10 Juli 2021. 


\section{Rumusan Masalah}

1. Bagaimana politik hukum ketentuan pidana atas Undang-Undang Nomor 22 Tahun 2001 tentang Minyak dan Gas Bumi?

2. Apa dampak bencana lumpur lapindo terhadap lingkungan dan kesehatan masyarakat?

\section{Tujuan Penelitian}

1. Untuk mengetahui dan menganalisis politik hukum ketentuan pidana atas Undang-Undang Nomor 22 Tahun 2001 tentang Minyak dan Gas Bumi.

2. Untuk mengetahui dan mengkaji dampak semburan lumpur lapindo terhadap lingkungan dan kesehatan masyarakat.

\section{Metode Penelitian}

Penelitian ini bersifat normatif dengan pendekatan perundang-undangan dan dianalisa menggunakan metode kualitatif. Sumber data yang digunakan untuk mengolah data menggunakan sumber data sekunder melalui bahan hukum primer, bahan hukum sekunder, dan bahan hukum tersier, seperti studi kepustakaan dan undang-undang.

\section{Hasil Penelitian dan Pembahasan}

Politik Hukum Ketentuan Pidana atas Undang-Undang Nomor 22 Tahun 2001 tentang Minyak dan Gas Bumi

Minyak dan Gas Bumi atau biasa disingkat Migas diatur di dalam UndangUndang Nomor 22 Tahun 2001. Pengertian dari minyak bumi menurut Pasal 1 ayat (1) Undang-Undang Migas adalah hasil proses alami berupa hidrokarbon yang dalam kondisi tekanan dan temperatur atmosfer berupa fasa cair atau padat, termasuk aspal, lilin mineral atau ozokerit, dan bitumen yang diperoleh dari proses penambangan, tetapi tidak termasuk batubara atau endapan hidrokarbon lain yang berbentuk padat yang diperoleh dari kegiatan yang tidak berkaitan dengan kegiatan usaha Minyak dan Gas Bumi. ${ }^{8}$ Kemudian pengertian dari Gas Bumi adalah hasil proses alami berupa hidrokarbon yang dalam kondisi tekanan dan temperatur atmosfer berupa fasa gas yang diperoleh dari proses penambangan Minyak dan Gas Bumi. ${ }^{9}$

Peraturan perundang-undangan yang mengatur tentang minyak dan gas, dapat dilihat pada berbagai peraturan perundang-undangan, tetapi sejak

\footnotetext{
${ }^{8}$ Pasal 1 ayat (1) Undang-Undang Nomor 22 Tahun 2001 tentang Minyak dan Gas Bumi.

${ }^{9}$ Pasal 1 ayat (2) Undang-Undang Nomor 22 Tahun 2001 tentang Minyak dan Gas Bumi.
} 
berlakunya Undang-Undang Nomor 22 Tahun 2001, peraturan perundangundangan yang lain, yaitu Undang-Undang Nomor 44 Prp Tahun 1960 tentang Pertambangan Minyak dan Gas Bumi, Undang-Undang Nomor 15 Tahun 1962 tentang Penetapan Peraturan Pemerintah Pengganti Undang-Undang Nomor 2 Tahun 1962 tentang Kewajiban Perusahaan Minyak Memenuhi Kebutuhan Dalam Negeri, Undang-Undang Nomor 8 Tahun 1971 tentang Pertamina, UndangUndang Nomor 10 Tahun 1974 tentang Perubahan Undang-Undang Nomor 8 Tahun 1971 Pertamina tidak berlaku lagi. Namun peraturan pelaksanaan dari keempat undang-undang tersebut tetap berlaku sepanjang tidak bertentangan atau belum diganti dengan peraturan baru berdasarkan Undang-Undang Nomor 22 Tahun 2001 tentang Minyak dan Gas Bumi. Pertimbangan ditetapkan UndangUndang Migas adalah sebagai berikut:

a. Pembangunan nasional harus diarahkan kepada terwujudnya kesejahteraan rakyat dengan melakukan reformasi di segala bidang kehidupan berbangsa dan bernegara berdasarkan Pancasila dan UUD 1945.

b. Minyak dan gas bumi merupakan sumber daya alam strategis tidak terbarukan yang dikuasai oleh negara serta merupakan komoditas vital yang menguasai hajat hidup orang banyak dan mempunyai peranan penting dalam perekonomian nasional sehingga pengelolaannya harus dapat secara maksimal memberikan kemakmuran dan kesejahteraan rakyat.

c. Kegiatan usaha minyak dan gas bumi mempunyai peranan penting dalam memberikan nilai tambah secara nyata kepada pertumbuhan ekonomi nasional yang meningkat dan berkelanjutan. ${ }^{10}$

Migas mempunyai peran yang sangat strategis di dalam perekonomian nasional dalam arti sebagai komoditi yang menguasai hidup orang banyak. Pengaturan dan pengelolaannya diperlukan peran pemerintah. Dalam hal ini, pemerintah tetap mengacu pada tugas untuk meningkatkan efisiensi dengan membentuk pengawasan, pelaksanaan kontrak kerjasama dalam rangka mengamankan penerimaan negara, menjamin kelangsungan ketersediaan sumber daya alam melalui optimasi pengembangan dan proses produksi lapangan yang baik. ${ }^{11}$

Setelah berlangsungnya undang-undang migas, maka kekhawatiran tentang pilar kekuasaan, penegakan hukum dan masyarakat menjadi kenyataan. Hal ini dikarenakan terdapatnya penolakan masyarakat terhadap undang-undang ini terealisasi melalui gugatan ke Mahkamah Konstitusi, walaupun gugatannya tidak dapat diterima seluruhnya. Begitu pula tentang penegakan hukum di bidang

${ }^{10}$ Salim HS, Hukum Pertambangan di Indonesia, PT Rajagrafindo Persada, Jakarta, 2014, hlm. 234-235.

${ }^{11}$ Syaiful Bakhri, Hukum Migas Telaah Penggunaan Hukum Pidana dalam Perundang-Undangan, Total Media, Jakarta, 2012, hlm. 73. 
migas, putusan pengadilan mencerminkan suatu kesalahan pada individu pelaku, tetapi tidak menarik korporasi dalam suatu peristiwa pidana. Maka suatu keengganan untuk memidanakan korporasi. Pada pengadilan pidana tentang tanpa izin untuk melakukan segala kegiatan industri migas, tercermin dari putusan pengadilan yang dapat dipersalahkan hanya pelaku saja, dan badan hukum hingga sekarang belum mendapatkan perhatian dalam putusan peradilan pidana. ${ }^{12}$

Menurut sumber-sumber berita yang telah penulis cermati, bahwa semburan lumpur panas terjadi akibat kesalahan PT Lapindo sendiri. Kesalahan tersebut adalah PT Lapindo tidak mengindahkan prosedural pengeboran yang baik dan dilakukan dengan sengaja. Kesalahan utama yang disengaja tersebut memuat tidak dipatuhinya ketentuan dalam prosedur operasi baku yang telah digunakan seluruh industri minyak dan gas di dunia. Pengeboran itu juga dilakukan dengan tidak melaksanakan pemasangan selubung pelindung (casing) apapun. ${ }^{13}$

PT Lapindo diduga sengaja menghemat biaya operasional dengan tidak memasang casing. Jika dilihat dari perspektif ekonomi, keputusan pemasangan casing berdampak pada besarnya biaya yang dikeluarkan PT Lapindo. Medco, selaku salah satu pemegang saham wilayah Blok Brantas, dalam surat bernomor MGT-008/JKT/06 telah memperingatkan PT Lapindo untuk memasang casing atau selubung bor sesuai dengan standar operasional pengeboran minyak dan gas. Namun, entah mengapa PT Lapindo sengaja tidak memasang casing, sehingga pada saat terjadi underground out lumpur yang ada di perut bumi menyembur keluar. ${ }^{14}$

Aturan pemasangan selubung pelindung (casing) $95 / 8$ inci sudah tertera dalam program pengeboran yang disepakati oleh para stake holder dan disetujui BP MIGAS. Kersam Sumanta, anggota Drilling Engineers Club dan mantan anggota Tim Nasional Penanggulangan Lumpur Lapindo menjelaskan, PT Lapindo tidak mematuhi kaidah operasional yang telah dibakukan para ahli pemboran sebagai Prosedur Operasi Standar. Uji kekuatan formasi di bawah casing 13 5/8 inci yang dipasang di 1.092 meter tidak dilakukan dengan benar sehingga mengakibatkan perhitungan menjadi salah. Sesuai aturan dan anjuran Medco, PT Lapindo semestinya memasang selubung 9 5/8 inci di 2.591 meter. Namun, PT Lapindo tidak memedulikannya.

${ }^{12}$ Ibid., hlm. 74.

${ }^{13}$ Elmaghfira Putri Elika, Risna Resnawaty, dan Arie Surya Gutama, "Bencana Sosial Kasus Lumpur PT. Lapindo Brantas Sidoarjo, Jawa Timur”, Jurnal Penelitian \& PKM, No. 2, Vol. 4, Tahun 2017, hlm. 6.

${ }^{14}$ Agustinus W. Dewantara, "Merefleksikan Hubungan Antara Etika Aristotelian dan Bisnis dengan Studi Kasus Lumpur Lapindo", Jurnal Filsafat Arete, No. 01, Vol. 02, Tahun 2013, hlm. 5. 
Selain itu, ada prosedur mencabut atau memasukkan rangkaian pipa bor dan pahat pada saat mencabut string mengalami tambahan beban, tetapi tidak dihiraukan oleh PT Lapindo. Hal yang lebih fatal adalah batasan tekanan maksimum di permukaan tidak dipatuhi oleh operator dan insinyur pengeboran PT Lapindo ketika menanggulangi semburan sehingga melebihi kekuatan formasi di bawah selubung 13 5/8 di 1.092 meter yang berakibat terjadinya rekahan sampai ke permukaan yang akhirnya menjadi jalan keluar lumpur dari dalam lubang bor. ${ }^{15}$

Pada 27 Mei 2006 saat gempa mengguncang Yogyakarta, selang 10 menit setelah gempa terjadi, lumpur panas masuk ke dalam lubang pengeboran. PT Lapindo meneruskan pengeboran selama 6 jam sampai kedalaman 2.834 meter. PT Lapindo memutuskan untuk menghentikan pengeboran dan menarik mata bor ke permukaan tanah. Saat bor sudah dikeluarkan semua, lumpur mulai mengalir dari lubang. PT Lapindo berusaha menutup lubang tersebut dengan semen dan berhasil, sehingga lumpur tidak kembali ke luar dari lubang pengeboran tersebut. Pada 28 Mei 2006 atau esok harinya, ternyata cairan yang mengaliri seluruh lubang bor menendang lapisan tanah di sekitar lubang pengeboran yang ternyata tidak cukup kuat menahan tekanan dari cairan tersebut. Akibatnya, lapisan tanah di sekeliling lubang pengeboran retak, dan keluarlah cairan dari retakan-retakan tersebut. ${ }^{16}$

Uraian di atas telah menjelaskan bahwa PT Lapindo telah lalai dalam mengaplikasikan prosedural pengeboran, tetapi hingga saat ini PT Lapindo tidak terjerat hukum. Hasil analisis Penulis hal ini dikarenakan di Undang-Undang Migas tidak mengatur secara lengkap mengenai Ketentuan Pidananya. Pada Bab XI Ketentuan Pidana UU Nomor 20 Tahun 2001 disebutkan larangan dan kejahatan dalam UU Migas, berikut rincian pasalnya: ${ }^{17}$

1. Pasal 51 ayat (1): Setiap orang yang melakukan Survei Umum sebagaimana dimaksud dalam Pasal 19 ayat (1) tanpa hak dipidana dengan pidana kurungan paling lama 1 (satu) tahun atau denda paling tinggi Rp10.000.000.000,00 (sepuluh miliar rupiah).

2. Pasal 51 ayat (2): Setiap orang yang mengirim atau menyerahkan atau memindahtangankan data sebagaimana dimaksud dalam Pasal 20 tanpa hak dalam bentuk apa pun dipidana dengan pidana kurungan paling lama 1 (satu) tahun atau denda paling tinggi Rp10.000.000.000,00 (sepuluh miliar rupiah).

15 Kompas.com, https://nasional.kompas.com/read/2012/08/07/19093138/ Nasional, "Pakar: Lumpur Sidoarjo Murni Kesalahan Pengeboran”, diakses 7 Juli 2021.

${ }^{16}$ Elmaghfira Putri Elika, Risna Resnawaty, dan Arie Surya Gutama, "Bencana Sosial..., Op. Cit., hlm. 6.

${ }^{17}$ Bab XI Ketentuan Pidana Undang-Undang Nomor 22 Tahun 2001 tentang Minyak dan Gas Bumi. 
3. Pasal 52: Setiap orang yang melakukan Eksplorasi dan/atau Eksploitasi tanpa mempunyai Kontrak Kerja Sama sebagaimana dimaksud dalam Pasal 11 ayat (1) dipidana dengan pidana penjara paling lama 6 (enam) tahun dan denda paling tinggi Rp60.000.000.000,00 (enam puluh miliar rupiah).

4. Pasal 53: Setiap orang yang melakukan : a. Pengolahan sebagaimana dimaksud dalam Pasal 23 tanpa Izin Usaha Pengolahan dipidana dengan pidana penjara paling lama 5 (lima) tahun dan denda paling tinggi Rp50.000.000.000,00 (lima puluh miliar rupiah); b. Pengangkutan sebagaimana dimaksud dalam Pasal 23 tanpa Izin Usaha Pengangkutan dipidana dengan pidana penjara paling lama 4 (empat) tahun dan denda paling tinggi Rp40.000.000.000,00 (empat puluh miliar rupiah); c. Penyimpanan sebagaimana dimaksud dalam Pasal 23 tanpa Izin Usaha Penyimpanan dipidana dengan pidana penjara paling lama 3 (tiga) tahun dan denda paling tinggi Rp30.000.000.000,00 (tiga puluh miliar rupiah); d. Niaga sebagaimana dimaksud dalam Pasal 23 tanpa Izin Usaha Niaga dipidana dengan pidana penjara paling lama 3 (tiga) tahun dan denda paling tinggi Rp30.000.000.000,00 (tiga puluh miliar rupiah).

5. Pasal 54: Setiap orang yang meniru atau memalsukan Bahan Bakar Minyak dan Gas Bumi dan hasil olahan sebagaimana dimaksud dalam Pasal 28 ayat (1) dipidana dengan pidana penjara paling lama 6 (enam) tahun dan denda paling tinggi Rp60.000.000.000,00 (enam puluh miliar rupiah).

6. Pasal 55: Setiap orang yang menyalahgunakan Pengangkutan dan/atau Niaga Bahan Bakar Minyak yang disubsidi Pemerintah dipidana dengan pidana penjara paling lama 6 (enam) tahun dan denda paling tinggi Rp60.000.000.000,00 (enam puluh miliar rupiah).

Jika kita cermati pasal-pasal di atas tidak ada disebutkan pelanggaran mengenai kesalahan prosedural yang dilakukan oleh perusahaan. Seharusnya di Undang-Undang Migas ditambahkan pasal mengenai kesalahan prosedural yang dilakukan oleh perusahaan beserta jerat pidana dan dendanya. Jika pasal ini diatur, maka PT Lapindo mungkin sudah mendapat jerat hukum karena telah melanggar ketentuan pasal mengenai kesalahan prosedural pengeboran dan telah menyebabkan pencemaran lingkungan akibat semburan lumpur panas dan telah banya $\mathrm{k}$ menelan korban jiwa, yang mana juga banyak warga sekitar rugi baik materil dan immateril.

\section{Dampak Bencana Lumpur Lapindo terhadap Lingkungan dan Kesehatan Masyarakat}

Kondisi air dan tanah pasca semburan lumpur lapindo jauh berbeda dengan kondisi sebelum semburan lumpu lapindo terjadi. Kondisinya berubah secara signifikan. Pencemaran lingkungan yang terjadi yaitu lahan pertanian dan perkebunan sekitar semburan lumpu lapindo mulai tidak produktif, semula 
subur menjadi tandus yang menyebabkan tanaman mengalami gagal panen. Selain itu terjadi krisis air bersih. Kualitas air yang berada di sekitar semburan lumpur lapindo mengalami perubahan rasa dan kualitas. Rasa air berubah menjadi pahit dan asin, sehingga tidak dapat dimanfaatkan lagi oleh masyarakat. Warna air yang awalnya jernih berubah menjadi keruh dan warna yang kekuning-kuningan. ${ }^{18}$

Selain air dan tanah, kondisi udara di kawasan semburan lumpur tidak baik, salah satu penyebabnya adalah kandungan kimia yang terkandung di lumpur yang terbawa oleh angin sehingga menyebabkan bau yang tidak sedap seperti bau selokan dan tinja yang jangkauannya sampai lebih dari 20 kilometer. ${ }^{19}$ Semburan lumpur lapindo ini menunjukkan banyak dampak buruk, baik secara fisik, psikis, dan sosial ekonomi. Air dan lingkungan yang tercemar dan tidak bersih menyebabkan mayoritas korban terserang penyakit kulit (scabies) dan paruparu oleh asap gas yang menyengat sehingga menyebabkan sesak napas sampai pada akhirnya ada beberapa korban yang meninggal.

Berdasarkan Data dari Puskesmas Porong menunjukkan sejumlah penyakit terus meningkat sejak tahun 2006. Penderita infeksi saluran pernapasan pada 2005 sebanyak 24.719 orang, sedangkan pada 2009 meningkat pesat sebanyak 52.543 orang. ${ }^{20}$ Sementara dampak psikis yang dialami korban adalah kecemasan, depresi, stress sampai gangguan jiwa. ${ }^{21}$ Dampak psikis terjadi karena semburan lumpur lapindo telah menenggelamkan rumah, sawah, sekolah, dll yang telah sejak lama memberikan kenangan bagi mereka.

Kandungan kimia yang terkandung dalam lumpur sangat berbahaya bagi kesehatan masyarakat. Lumpur yang mengandung logam dapat menyebabkan infeksi saluran pernapasan, iritasi kulit dan kanker. Selain logam, lumpur mengandung fenol yang menyebabkan sel darah merah pecah (hemolisis). Jantung berdebar (cardiac aritma), dan gangguan ginjal.22 Senyawa fenol atau asam karbolat yang memiliki bau khas. Keberadaan fenol bisa menjadi sumber pencemaran yang membahayakan kehidupan manusia maupun hewan air.

18 Adelia Suryaningsih dan Baiq Lily Handayani, "Bertahan Hidup dalam Kubangan Lumpur (Studi tentang Korban Lumpur Lapindo di Desa Glagaharum Kecamatan Porong Sidoarjo)”, Jurnal e-SOSPOL, Vol. IV, Edisi 1, Tahun 2017, hlm. 2.

19 Siti Nuurlaily Rukmana dan Moch. Shofwan, "Dampak Risiko Secondary Hazard di Sekitar Bencana Lumpur Lapindo Terhadap Perubahan Lingkungan”, Jurnal Pembangunan Wilayah dan Kota, No. 4, Vol. 14, Tahun 2018, hlm. 5.

20 Tania Ayu Apsari, "Bingkai Berita Bencana Lumpur Lapindo di Media Online”, Jurnal Komunikasi dan Kajian Media, No. 1, Vol. 2, Tahun 2018, hlm. 4.

21 Aris Setiawan dan Niken Titi Pratitis, "Religiusitas, Dukungan Sosial dan Resiliensi Korban Lumpur Lapindo Sidoarjo”, Jurnal Psikologi Indonesia, No. 02, Vol. 4, Tahun 2015, hlm. 2.

22 Agustinus W. Dewantara, “Merefleksikean Hubungan Antara..., Op.Cit., hlm. 4. 
Sejumlah efek pada manusia akibat menghirup fenol di udara yaitu efek jangka pendek di antaranya adalah iritasi pernapasan, sakit kepala, dan mata terbakar. Sementara itu, efek kronis paparan tingkat tinggi fenol adalah kelemahan, nyeri otot, anoreksia, penurunan berat badan, dan kelelahan. ${ }^{23}$ Kemudian lumpur lapindo juga mengandung senyawa hidrogen sulfida, gas beracun dan berbau seperti telur busuk. Seorang pekerja lumpur lapindo di Porong, Kabupaten Sidoarjo, pingsan akibat menghirup senyawa hidrogen sulfida yang terkandung pada asap pekat dari lumpur panas. ${ }^{24}$ Selain itu, lumpur lapindo juga mengandung gas metana. Badan Penanggulangan Lumpur Lapindo (BPLS) mencatat kandungan gas metana yang keluar di sekitar lumpur lapindo itu tinggi yang mana kondisinya berbahaya dan mudah terbakar dengan kadar gas yang mudah terbakar mencapai 100 persen. ${ }^{25}$

Apabila ditinjau dari uraian pada paragraf di atas, penulis mengkaji Pasal 1 angka 6 Undang-Undang Migas, menjelaskan tentang survei umum, berikut bunyi pasal tersebut: "Survei Umum adalah kegiatan lapangan yang meliputi pengumpulan, analisis, dan penyajian data yang berhubungan dengan informasi kondisi geologi untuk memperkirakan letak dan potensi sumber daya Minyak dan Gas Bumi di luar Wilayah Kerja". ${ }^{26}$ Seharusnya pengumpulan, analisis, dan penyajian data yang dilakukan tidak hanya sebatas informasi kondisi geologi saja, tetapi juga mengenai kandungan bahan kimia yang terpendam di lokasi pengeboran karena dampak gas beracun pasti membahayakan kesehatan masyarakat sekitar.

Oleh karena itu, untuk kedepannya diharapkan kepada pembuat undangundang untuk merevisi Undang-Undang Nomor 22 Tahun 2001 tentang Minyak dan Gas Bumi khususnya mengenai Ketentuan Pidana, agar badan hukum yang melanggar ketentuan dapat dijerat hukuman yang setimpal dengan perbuatan yang telah dilakukan dan perbuatan tersebut telah merugikan masyarakat.

\section{Penutup}

1. Pada Ketentuan Pidana dalam Bab IX Undang-Undang Nomor 22 Tahun 2001 tentang Minyak dan Gas Bumi seharusnya ditambahkan pelanggaran mengenai kesalahan prosedur standar dalam menjalankan kegiatan pengeboran di wilayah kerja yang sudah mendapat izin dari pemerintah.

${ }^{23}$ https://www.cnnindonesia.com/gaya-hidup/20150529173547-255-56592/bahaya-mematikan-senyawafenol-pada-lumpur-lapindo, "Bahaya Mematikan Senyawa Fenol pada Lumpur Lapindo", diakses 10 Juli 2021.

${ }^{24}$ https://news.detik.com/berita/775185/pekerja-lumpur-lapindo-pingsan-diduga-hirup-gas-beracun,

"Pekerja Lumpur Lapindo Pingsan Diduga Hirup Gas Beracun”, diakses 10 Juli 2021.

${ }^{25}$ https://nasional.tempo.co/read/356244/kandungan-gas-metana-lumpur-lapindo-berbahava,

"Kandungan Gas Metana Lumpur Lapindo Berbahaya”, diakses 10 Juli 2021.

26 Pasal 1 angka 6 Undang-Undang Nomor 22 Tahun 2001 tentang Minyak dan Gas Bumi. 
2. Pada ketentuan Pasal 1 angka 6 Undang-Undang Nomor 22 Tahun 2001 tentang Minyak dan Gas Bumi seharusnya di tambahkan survei umum terhadap kandungan zat kimia yang terkandung di dalam wilayah kerja pengeboran, jadi tidak hanya survei umum mengenai kondisi geologis nya saja.

\section{Daftar Pustaka}

\section{Buku}

Bakhri, Syaiful, Hukum Migas Telaah Penggunaan Hukum Pidana dalam PerundangUndangan, Total Media, Jakarta, 2012.

HS, Salim, Hukum Pertambangan di Indonesia, PT Rajagrafindo Persada, Jakarta, 2014.

Muchtar, Masrudi, Noraida, dan Abdul Khair, Hukum Kesehatan Lingkungan (Kajian Teoritis dan Perkembangan Pemikiran), Pustaka Baru Press, Yogyakarta, 2016.

Rahmadi, Takdir, Hukum Lingkungan di Indonesia, PT Rajagrafindo Persada, Depok, 2015.

Wahid, Yunus, Pengantar Hukum Lingkungan, Prenadamedia Group, Jakarta, 2018.

\section{Jurnal}

Anis Farida, "Jalan Panjang Penyelesaian Konflik Kasus Lumpur Lapindo", Jurnal Ilmu Sosial dan Ilmu Politik, No. 2, Vol. 17, 2013

Tania Ayu Apsari, "Bingkai Berita Bencana Lumpur Lapindo di Media Online”, Jurnal Komunikasi dan Kajian Media, No. 1, Vol. 2, Tahun 2018.

Agustinus W. Dewantara, "Merefleksikan Hubungan Antara Etika Aristotelian dan Bisnis dengan Studi Kasus Lumpur Lapindo", Jurnal Filsafat Arete, No. 01, Vol. 02, Tahun 2013.

Elmaghfira Putri Elika, Risna Resnawaty, dan Arie Surya Gutama, "Bencana Sosial Kasus Lumpur PT. Lapindo Brantas Sidoarjo, Jawa Timur", Jurnal Penelitian \& PKM, No. 2, Vol. 4, Tahun 2017.

Siti Nuurlaily Rukmana, dan Moch. Shofwan, "Dampak Risiko Secondary Hazard di Sekitar Bencana Lumpur Lapindo Terhadap Perubahan Lingkungan", Jurnal Pembangunan Wilayah dan Kota, No. 4, Vol. 14, Tahun 2018.

Satrio, Bungkus Pratikno dan Paston Sidauruk, "Studi Asal-Usul Air Lumpur Lapindo Periode 2007-2012 Menggunakan Isotop Alam", Jurnal Ilmiah Isotop dan Radiasi, No. 2, Vol. 8, Tahun 2012.

Aris Setiawan, dan Niken Titi Pratitis, "Religiusitas, Dukungan Sosial dan Resiliensi Korban Lumpur Lapindo Sidoarjo", Jurnal Psikologi Indonesia, No. 02, Vol. 4, Tahun 2015.

Adelia Suryaningsih, dan Baiq Lily Handayani, "Bertahan Hidup dalam Kubangan Lumpur (Studi tentang Korban Lumpur Lapindo di Desa Glagaharum Kecamatan Porong Sidoarjo)", Jurnal e-SOSPOL, Vol. IV, Edisi 1, Tahun 2017. 


\section{Peraturan Perundang-Undangan}

Undang-Undang Nomor 22 Tahun 2001 tentang Minyak dan Gas Bumi.

\section{Data Elektronik}

https://nasional.kompas.com/read/2012/08/07/19093138/ Nasional, "Pakar: Lumpur Sidoarjo Murni Kesalahan Pengeboran".

https:/ / www.cnnindonesia.com/gaya-hidup/20150529173547-25556592/bahaya-mematikan-senyawa-fenol-pada-lumpur-lapindo, "Bahaya Mematikan Senyawa Fenol pada Lumpur Lapindo".

https:/ / news.detik.com/berita/775185/pekerja-lumpur-lapindo-pingsandiduga-hirup-gas-beracun, "Pekerja Lumpur Lapindo Pingsan Diduga Hirup Gas Beracun".

https://nasional.tempo.co/read/356244/kandungan-gas-metana-lumpurlapindo-berbahaya, "Kandungan Gas Metana Lumpur Lapindo Berbahaya".

https://www.voaindonesia.com/a/kasus-lapindo-12-tahun-semburan-lumpurancam-kesehatan-warga/4415812.html, "Kasus Lapindo: 12 Tahun Semburan Lumpur Ancam Kesehatan Warga". 